\title{
Evaluation of different traps for the invasive leaf miner, Liriomyza huidobrensis in potato (Solanum tuberosum) fields of the Nilgiris district, Tamil Nadu, India
}

\author{
S. S. Monica* iD \\ Department of Agricultural Entomology, Tamil Nadu Agricultural University, Coimbatore - \\ 641003 (Tamil Nadu), India \\ B. Vinothkumar \\ Department of Agricultural Entomology, Tamil Nadu Agricultural University, Coimbatore - \\ 641003 ( Tamil Nadu), India \\ S.V. Krishnamoorthy \\ Department of Agricultural Entomology, Tamil Nadu Agricultural University, Coimbatore - \\ 641003 (Tamil Nadu), India

\section{Rajendran} \\ Department of Plant Pathology, Tamil Nadu Agricultural University, Coimbatore \\ 641003 (Tamil Nadu), India \\ *Corresponding author. Email: monicasubburaj30@gmail.com
}

\section{Article Info}

https://doi.org/10.31018/ jans.v13i4.3096

Received: October 19, 2021

Revised: December 11, 2021

Accepted: December 15, 2021

\section{How to Cite}

Monica, S. S. et al. (2021). Evaluation of different traps for the invasive leaf miner, Liriomyza huidobrensis in potato (Solanum tuberosum) fields of the Nilgiris district, Tamil Nadu, India. Journal of Applied and Natural Science, 13(4), 1563 - 1570. https:// doi.org/10.31018/jans.v13i4.3096

\begin{abstract}
Potatoes are currently threatened by the pea leaf miner (Liriomyza huidobrensis Blanchard), an exotic, exceedingly polyphagous, and chemically resistant pest that attacks a wide range of crops, ornamental plants, and weeds. The present work was conducted to study the attractiveness of various traps to Liriomyza leaf miner, one of the invasive pests recently observed in potato fields of Kotagiri and Ooty in Nilgiris district of Tamil Nadu. A trial was conducted at these two different locations, the Nilgiris district, in 2021. The results revealed that among different traps tested for their efficacy in attracting the leaf miner, $L$. huidobrensis, yellow sticky trap was found to be more efficient in attracting adult leaf miner flies with the mean trap catches of 40.49 and 36.64 adult flies $/ 10 \mathrm{~cm}^{2}$ areas at Kotagiri and Ooty respectively. The peak population of leaf miners was recorded in the last week of April (45.67 adult flies $/ 10 \mathrm{~cm}^{2}$ areas) at Ooty and during the $3^{\text {rd }}$ week of June (52.33 adult flies $/ 10 \mathrm{~cm}{ }^{2}$ areas) at Kotagiri. The correlation study revealed a significant positive correlation of the trap catches with maximum temperature, diurnal variation (DV) and growing day degrees (GDD). Multiple regression equation was also developed, where the abiotic factors contributed $46.1 \%$ and $65.5 \%$ to the Liriomyza leaf miner population fluctuation in the potato ecosystem. The trappers may be used to determine the initial presence of a leaf miners' population and in projecting their future population through pest management models and management decisions.
\end{abstract}

Keywords: Leaf miner monitoring, Liriomyza huidobrensis, Potatoes, Traps, Weather

\section{INTRODUCTION}

The potato (Solanum tuberosum) is a temperate crop grown extensively in the subtropical regions of India. It is a herbaceous perennial crop that belongs to the family Solanaceae, which is grown for its edible tuber. Potatoes are the fourth important food crop in terms of world production, the other three being wheat, maize, and rice. It exceeds pre-existing staple crops by provid- ing more vitamins and nutrients to support life than any other crop (Reader, 2008). There are various constraints associated with potato production, among which insect pests are at the top of the list. Pertaining to potato production, insect loss accounts for about $15-25 \%$, according to Neupane (2000). A wide range of insects viz., Myzus persicae, leafhoppers, Empoasca fabae, potato cutworms, Agrotis spp., potato tuber moth, Phthorimaea operculella and leaf miners, Liri- 
omyza sp. can harm potato crops,-either directly by feeding on tubers and damaging the harvest or indirectly by feeding on leaves and stems and transmitting diseases. Recently, leaf miners of $L$. huidobrensis were observed to cause severe damage, resulting in a considerable yield reduction in potatoes in the Nilgiris district, Tamil Nadu. Hitherto in India, this pest has not been reported to infest potato. At Nilgiris, these invasive Liriomyza leaf miners were found to be the cause of major yield loss in potatoes during 2020-2021. The population of leaf miner in potatoes has to be monitored to accurately implement timely control measures. Traps serve as a tool for monitoring and managing the pest population on crops. The present research aimed to determine the most effective colour of sticky traps and bottle traps within the potato canopy to maximize adult leaf miner captures.

\section{MATERIALS AND METHODS}

Two field experiments were conducted on the potato variety Kufri Jyoti with seven trappers and three replications in a Randomized Block Design (RBD) with a plot size of $25 \mathrm{~m}^{2}$. The experiment was carried out during February-May (as an irrigated crop) at Kappachi, Ooty $\left(11.43^{\circ} \mathrm{N} 76.76^{\circ} \mathrm{E} ; 2,209 \mathrm{~m}\right)$ and during April-July (as a summer crop) at Kookal village, Kotagiri $\left(11.46^{\circ} \mathrm{N}\right.$ $76.88^{\circ} \mathrm{E} ; 1,847 \mathrm{~m}$ ). The experimental site was kept free from pesticides, and no chemical treatments were given in the selected potato fields. Two trap types, viz., sticky traps (yellow, white, blue) and bottle traps with casein and protein hydrolysate as mentioned below, were evaluated for their effectiveness in attracting leaf miner adults from sowing to harvesting of the crop at weekly intervals during the year 2021.

\begin{tabular}{ll}
\hline Trappers & Attractants \\
\hline Sticky traps & Yellow sticky trap \\
$\mathrm{T}_{1}$ & Blue sticky trap \\
$\mathrm{T}_{2}$ & White sticky trap \\
$\mathrm{T}_{3}$ & \\
Bottle traps & $10 \%$ Protein hydrolysate \\
$\mathrm{T}_{4}$ & $20 \%$ Protein hydrolysate \\
$\mathrm{T}_{5}$ & $10 \%$ Casein hydrolysate \\
$\mathrm{T}_{6}$ & $20 \%$ Casein hydrolysate \\
$\mathrm{T}_{7}$ &
\end{tabular}

Sticky trap: A yellow polythene sheet of $2 \times 3$ feet was fixed and coated with a thin layer of adhesive (castor oil). The boards were placed at $30 \mathrm{~cm}$ above ground level using wooden stakes, and the adhesive (Castor oil) was recouped each week.

Bottle trap: A bottle was filled with approximately 100 $\mathrm{ml}$ of the appropriate concentration of protein or casein hydrolysate. These traps were hung $60 \mathrm{~cm}$ above ground level from wooden stakes.
Weekly trap collections of leaf miners were visually examined and trap counts were made for $10 \mathrm{~cm}^{2}$ of the trap for leaf miner adult populations. The weather parameters like maximum temperature, minimum temperature, morning relative humidity, evening relative humidity, rainfall was obtained during different months and the derived parameters like diurnal variation (DV), relative temperature Disparity (RTD) and growing degree days (GDD) were subjected to correlation with the trap catches of leaf miner. The seven trappers were also subjected to ANOVA and DMRT in order to identify the most effective trap/attractant against leaf miner in potatoes.

\section{Statistical analysis}

The weekly trap catches were transformed to square root transformation before being subjected to an analysis of variance (ANOVA). Duncan's Multiple Range Test (DMRT) was used to differentiate the means of the significantly different trappers $(P<0.05)$. The level of significance was fixed at $\alpha=0.05$. All these procedures were carried out using AGRESS software.

\section{RESULTS AND DISCUSSION}

\section{Efficiency of different trap catches in attracting leaf miners}

The results of the field experiments conducted at two locations viz. Ooty and Kotagiri are shown in Tables 1 and 2 . The mean trap catches of seven trappers were $40.49,10.92,19.51,1.72,5.36,1.87$, and $4.36 / 10$ $\mathrm{cm}^{2}$ area at Ooty, and 36.64, 9.67, 16.67, 4.67, 3.85, 1.36 , and $4.82 / 10 \mathrm{~cm}^{2}$ area at Kotagiri (Tables 1 and 2). A fluctuating leaf miner population was observed in both locations, which might have been influenced by the abiotic factors (Fig. 1 and 2). All the trappers were found to be significantly different from each other. The mean trap catches of the yellow sticky trap were $36.64 / 10 \mathrm{~cm}^{2}$ area and $40.49 / 10 \mathrm{~cm}^{2}$ area respectively in the two locations, which was found to be higher when compared to the other trappers. Followed by the yellow sticky trap, the white sticky trap recorded mean catches of about 9.67 and $10.92 / 10 \mathrm{~cm}^{2}$ area. When compared with bottle trap (with $10 \%$ protein hydrolysate, $20 \%$ protein hydrolysate, $10 \%$ casein hydrolysate, $20 \%$ casein hydrolysate), the sticky trap was effective in attracting leaf miner adults in the potato ecosystem.

The order of effectiveness of different trappers were, yellow sticky trap (36.64) > white sticky trap (16.67) > blue sticky trap $(9.67)>20 \%$ casein hydrolysate $(4.82)$ $>10 \%$ protein hydrolysate $(4.67)>20 \%$ protein hydrolysate $(3.85)>10 \%$ casein hydrolysate $(1.36)$ at Kotagiri and yellow sticky trap (40.49) > white sticky trap $(19.51)>$ blue sticky trap $(10.92)>20 \%$ protein hydrolysate $(5.36)>20 \%$ casein hydrolysate $(4.36)>$ $10 \%$ casein hydrolysate $(1.87)>10 \%$ protein hydroly- 


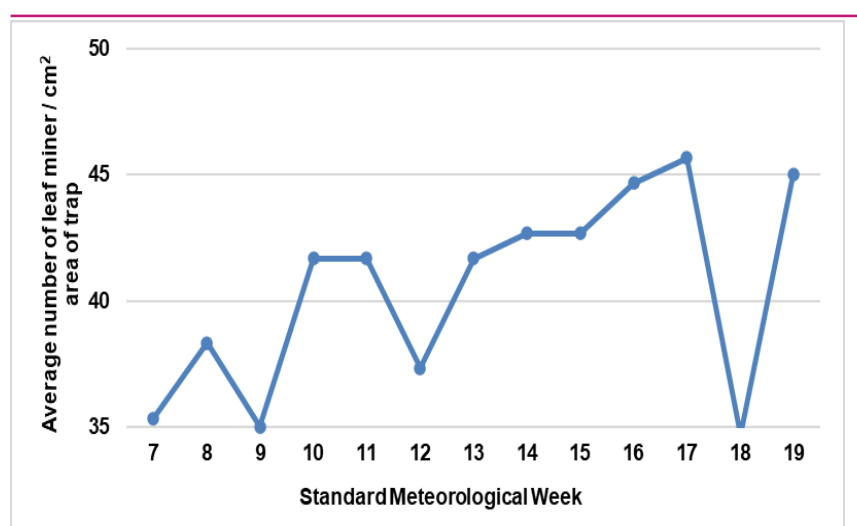

Fig. 1. Yellow sticky trap catches of L. huidobrensis in Kappachi, Ooty.

sate (1.72) at Ooty. The results of the field experiments conducted at two locations revealed that yellow sticky traps were found to be most effective in attracting adult leaf miners in potatoes among seven different traps used.

The results of the field trial conducted at Kookal, Kotagiri and Kappachi, Ooty revealed that among different traps tested for their efficacy in attracting the leaf miner, L. huidobrensis, yellow sticky trap found to be more efficient in attracting adult leaf miner flies with the mean trap catches of 36.64 adult flies/ $10 \mathrm{~cm}^{2}$ areas. The results revealed that there was a significant difference (at 5\%) in the trap catches of different traps. Also, trap catches were found to lower the population of adult leaf miners in potatoes. The results revealed that among different traps tested for their efficacy in attracting the leaf miner, $L$. huidobrensis, the yellow sticky trap was found to be more efficient in attracting adult leaf miner flies.

The mean trap catches of leaf miners recorded was 36.64 adult flies/ $10 \mathrm{~cm}^{2}$ areas of trap which was in accordance with the work of Chavez and Raman (1987), where the trap catches with a mean of 1194 leaf miners/week/trap was recorded at the La Molina experimental fields of International Potato Center. Unmole et al. (2001) in onion at Mauritius, Weintraub (2001) in potato at Israel and Durairaj et al. (2010) in tomato at India also reported similar results where yellow sticky trap was found to be most efficient in trapping higher number of leaf miner. Yabas (2000) also used yellow sticky trap to control leaf miner, Liriomyza spp. in tomatoes in greenhouses in Turkey. The yellow sticky traps used in our experiment was a polythene sheet smeared with castor oil (adhesive) and placed at $30 \mathrm{~cm}$ above ground level. Similarly, Colting et al. (2003) used yellow sticky traps to manage leaf miners in potatoes, where chrome yellow plastic plates with motor grease as sticky materials were used and staked at 30 to $60 \mathrm{~cm}$ above or beside the crop in Philippines. Our finding showed that yellow sticky trap was found to trap leaf miner adult populations in an effective manner, thus

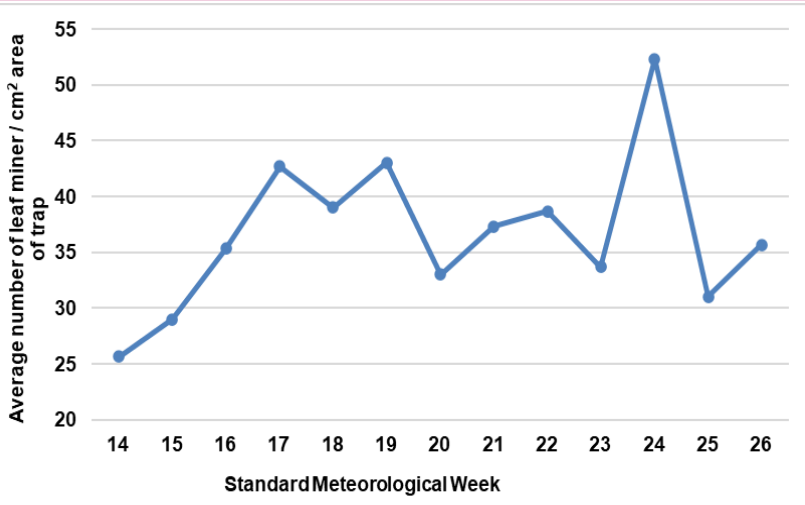

Fig. 2. Yellow sticky trap catches of L. huidobrensis in Kookal, Kotagiri.

reducing the leaf miner population to a considerable level. The same trends were reported in potatoes by Kroschel et al. (2012) at the high Andes and the coast of Peru and Rose et al. (2019) in southwestern Uganda, where trapping reduced leaf miner flies but did not effectively prevent yield reductions and larval mining and development.

\section{Correlation of trap catches of yellow sticky trap with weather parameters}

The study results indicated that the yellow sticky trap was most attractive among different traps, followed by the white sticky trap in attracting adult leaf miners, $L$. huidobrensis. Blue sticky trap and the bottle trap with protein hydrolysate and casein hydrolysate were the least attractive to leaf miner adults. Accordingly, the trap catches of the yellow sticky trap were compared with abiotic factors to study the influence of the key meteorological parameters on the incidence of leaf miner. Simple correlation matrices were calculated between the adult trap catches (as dependent variables) and the weather parameters (as independent variables) (Tables 3 and 4; Figs. 3 and 4).

When the potato was grown as an irrigated crop at Kappachi, Ooty, the average number of leaf miners observed was $35.33 / 10 \mathrm{~cm}^{2}$ area of trap during $2^{\text {nd }}$ week of February, and the population fluctuated depending upon the temperature. The population reached its peak in the second week of March (Fig.1), which coincided with the tuber developmental stage of the crop. The correlation studies revealed a significant positive correlation of trap catches with maximum temperature $\left({ }^{\circ} \mathrm{C}\right)$ and growing day degrees (GDD) and a positive correlation with minimum temperature $\left({ }^{\circ} \mathrm{C}\right)$, rainfall (mm) and diurnal variation (DV). Relative humidity (\%) and Relative temperature disparity (RTD) were negatively correlated with trap catches (Table 5). In order to derive a conclusion, multiple regression analysis was carried out. The multiple regression equation fit with weather parameters for trap catches, $\mathrm{Y}_{1}=5.901+$ 2.015 (T.max) - 0.564 (GDD) + 3.145, contributed 46.1 


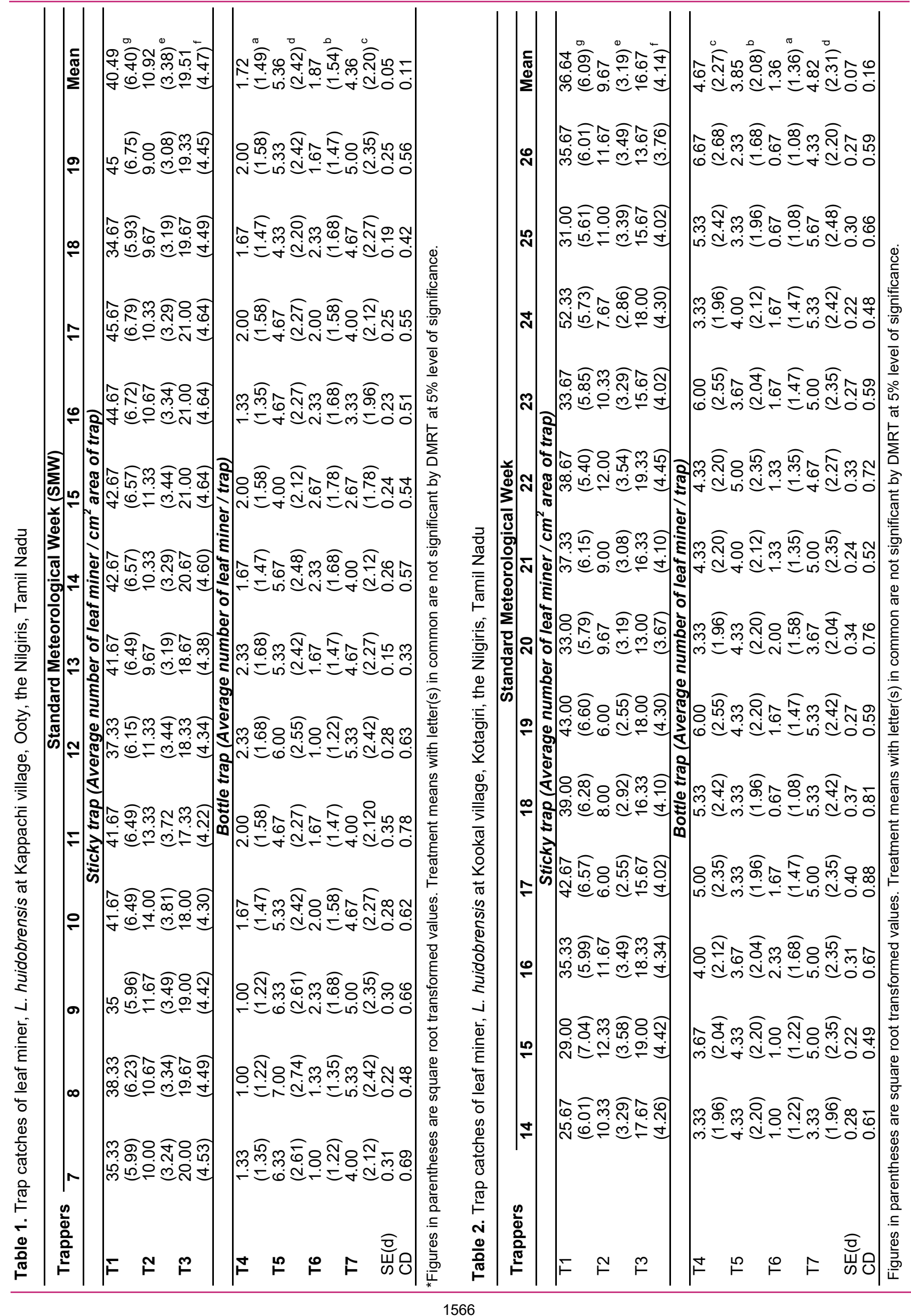




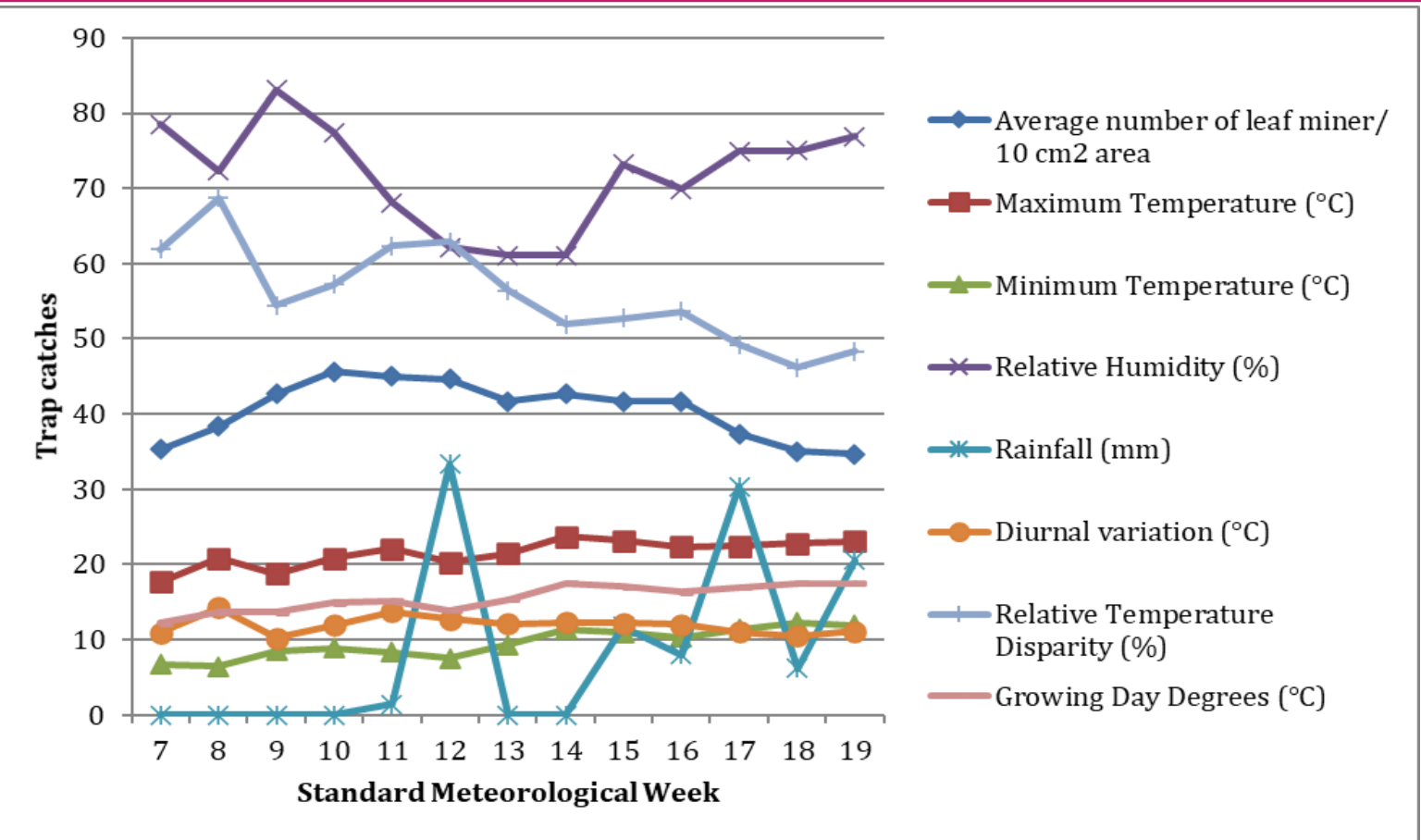

Fig. 3. Trap catches of $L$. huidobrensis in relation to abiotic factors at Kappachi, Ooty, Nilgiris district, Tamil Nadu (February- May).

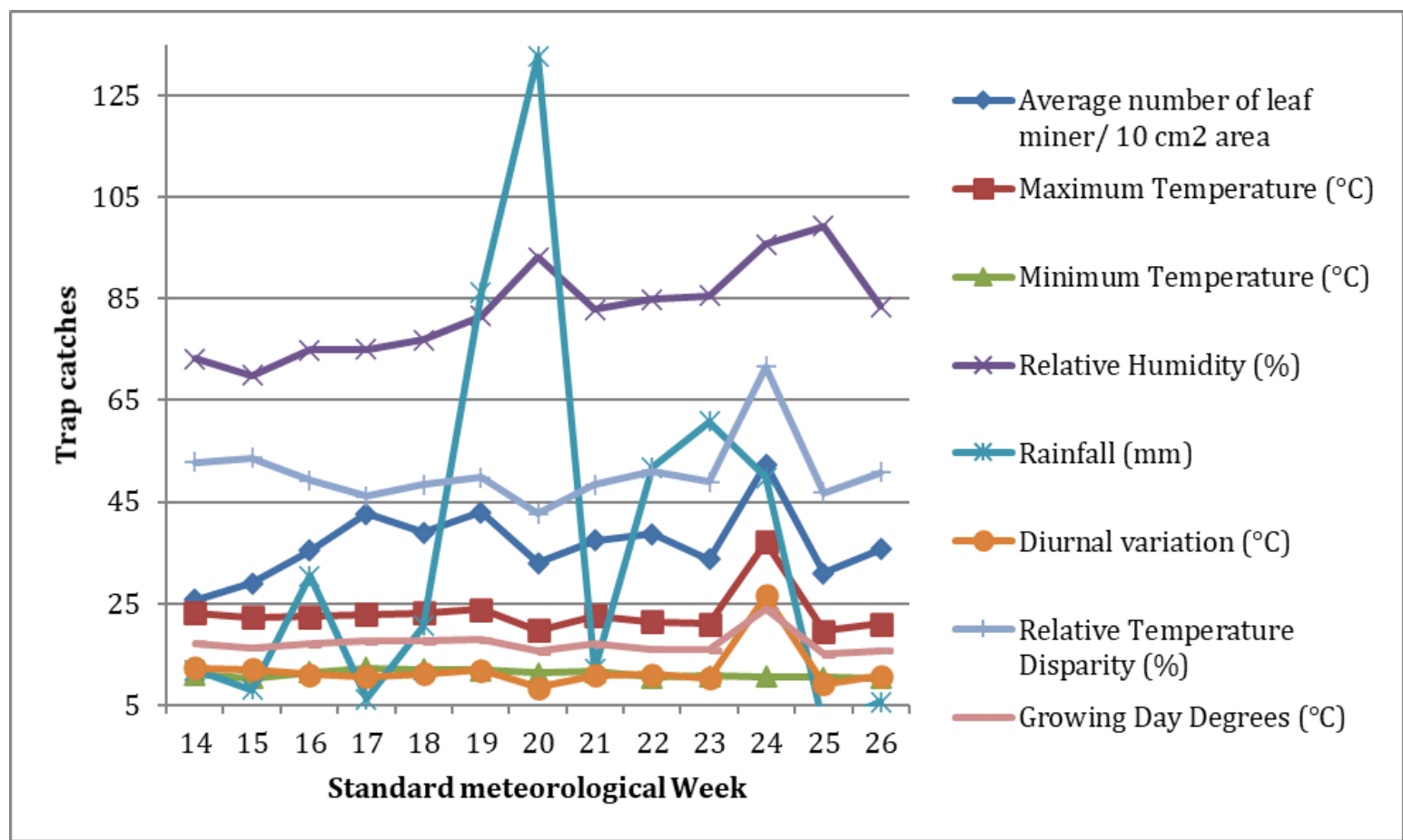

Fig. 4. Trap catches of L. huidobrensis in relation to abiotic factors at Kookal, Kotagiri, Nilgiris district, Tamil Nadu (April - July)

$\%$ of the influence in the leaf miner population fluctuation (Table 6).

Similarly, the result of the experiment at Kookal, Kotagiri, during the summer season, showed an average trap catch of $25.67 / 10 \mathrm{~cm}^{2}$ area of trap during the first week of April (Fig. 2). The population was gradually increased with increasing temperature, thus exhibiting a significant positive correlation with the temperature.
The peak population (52.33 adults $/ 10 \mathrm{~cm}^{2}$ area) was observed during the third week of June $\left(24^{\text {th }}\right.$ standard week), which coincides with the tuber formation stage. The correlation studies revealed a positive correlation with minimum temperature, relative humidity, rainfall, relative temperature disparity (RTD) and a significant and positive correlation with maximum temperature $\left({ }^{\circ} \mathrm{C}\right)$, diurnal variation (DV) and growing day degrees 


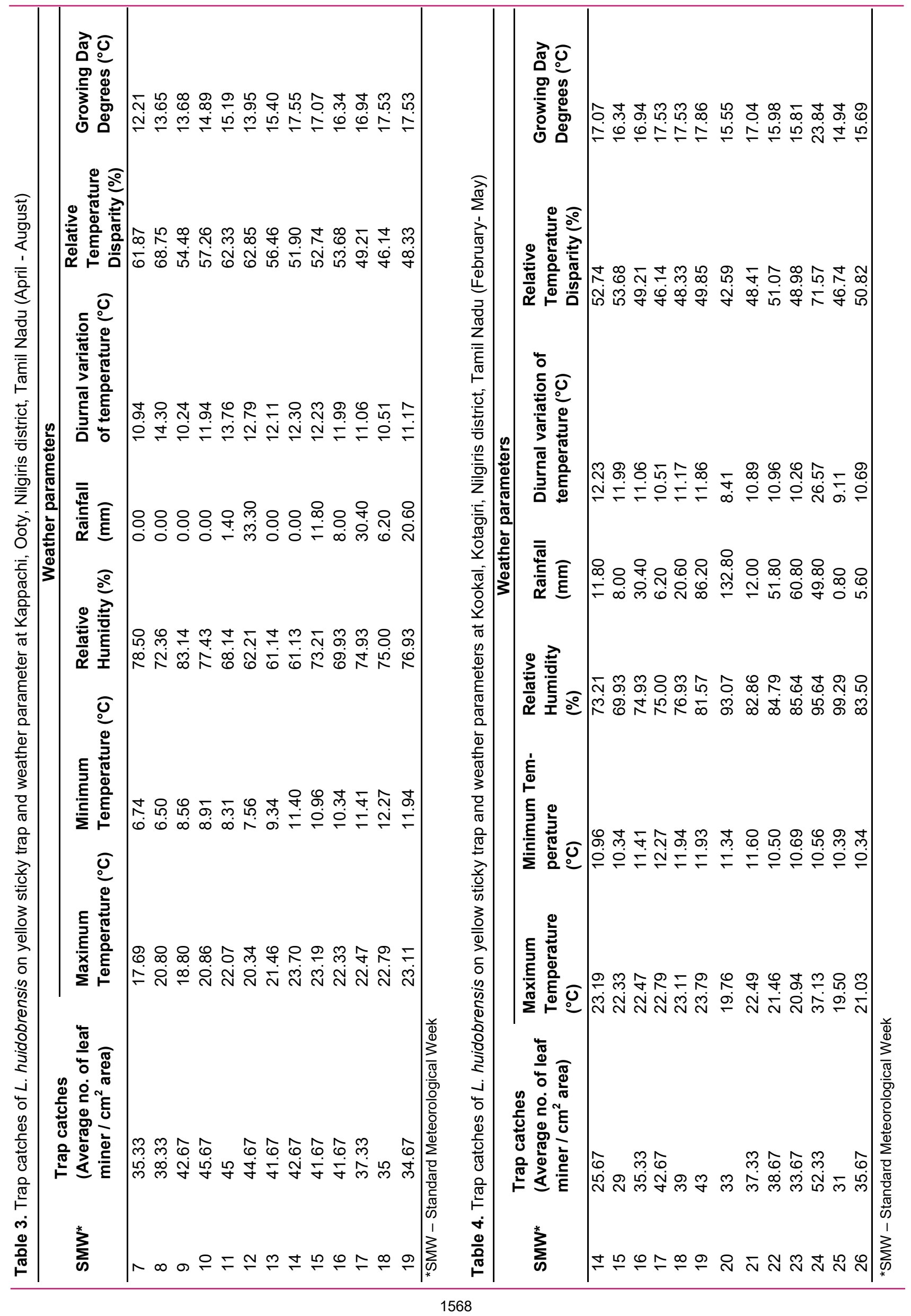


Monica, S. S. et al. / J. Appl. \& Nat. Sci. 13(4), 1563 - 1570 (2021)

Table 5. Correlation of trap catches of yellow sticky trap and weather parameters in potato

\begin{tabular}{lll}
\hline \multirow{2}{*}{ Weather parameter } & \multicolumn{2}{l}{$\begin{array}{l}\text { Correlation of Trap } \\
\text { catches (r) }\end{array}$} \\
\cline { 2 - 3 } & Ooty & Kotagiri \\
\hline Maximum temperature & $0.674^{*}$ & $0.727^{*}$ \\
Minimum temperature & $0.490^{\mathrm{NS}}$ & $0.299^{\mathrm{NS}}$ \\
Morning relative Humidity & $-0.259^{\mathrm{NS}}$ & $0.284^{\mathrm{NS}}$ \\
Rainfall & $0.301^{\mathrm{NS}}$ & $0.194^{\mathrm{NS}}$ \\
Diurnal variation (DV) & $0.195^{\mathrm{NS}}$ & $0.667^{\star}$ \\
Relative temperature disparity & $-0.322^{\mathrm{NS}}$ & $0.531^{\mathrm{NS}}$ \\
(RTD) & & \\
Growing degree days (GDD) & $0.608^{*}$ & $0.771^{*}$ \\
\hline
\end{tabular}

*Significant at $5 \%$; NS - Non-Significant

(GDD) (Table 5). The multiple regression equation fitted with weather parameters for trap catches, $Y_{2}=$ $30.880-163.415$ (T.max) - 80.500 (DV) + 1680224 (GDD) +4.666 , contributing $65.5 \%$ of th e fluctuation in the adult leaf miner population. Table 6 depicts the regression coefficient values to check the impact of weather factors on the leaf miner population. In the present study, it was reported that the temperature more influenced the population of leaf miner and a significant positive correlation was found between the trap catches and the maximum temperature in both the locations and was in line with Mazumdar and Bhuiya (2015) who studied the weather correlation of trap catches of leaf miner, Liriomyza sp. for three crops viz, tomato, French bean and cowpea. In the present experiment, the peak population was observed during the 2nd week of March and the first week of April, which coincides with the tuber formation and developmental stages in both locations, indicating that the pest directly affects the crop's yield.

The findings also support the result of Reddy and Kumar (2005) who indicated that the peak incidence of Liriomyza was noticed during March-April, which coincides with the vegetative and reproductive stages. Also, Shepard and Braun (1998) reported that the leaf miner populations were most severe in potatoes, especially towards the end of the wet season (March). A similar finding by Galande et al. (2004) reported that $L$. trifolii population was at peak during January to April in tomato crop and the maximum temperature showed a significant and positive correlation (0.872), whereas morning relative humidity showed significant but negative correlation (-0.578) with $L$. trifolii incidence. At the same time, a significant positive correlation was found between the trap catches of leaf miner and temperature for the crop tomato and cowpea and no relation for the french bean. The present finding agrees with the observations made by Ganapathy et al. (2010), who reported that the incidence of leaf miner L. trifolii (Burgess) in cowpea was least in November $(9.0 \%)$ and maximum in March $(32.5 \%)$, indicating that in the colder months the incidence was comparatively low (9.0 to $13.70 \%)$. The present findings are in line with Soltani et al. (2020) in chickpea against leaf miner, L. cicerina in North Tunisia. They reported that infestation with leaf miners was particularly prominent during the flowering and pod-setting stages at winter crops which were in line with the present findings where the leaf miner population attained its peak during the tuber formation stage (Reproductive stage). The study of the population fluctuation of $L$. huidobrensis from India is not reported so far. The present study may help to understand the abundance of $L$. huidobrensis and their control in the potato growing belts of Nilgiris district, Tamil Nadu.

\section{Conclusion}

The results revealed a significant difference in the trap catches of different traps. Among the traps tested, the yellow sticky trap was more effective in attracting the adult leaf miner. The trap catches were also greatly influenced by the weather parameters like maximum temperature, minimum temperature, relative humidity and rainfall. The population of leaf miner was found to be more influenced by the temperature. A significant positive correlation was found between the trap catches and the maximum temperature in both Ooty and Kotagiri in the Nilgiris districts of Tamil Nadu. Also, trap catches were found to lower the population of adult leaf miners, $L$. huidobrensis in potatoes. The peak population was observed in the tuber formation and developmental stages in both locations, which indicated that the pest directly affected the yield of the crop. It was

Table 6. Regression equation and coefficient of determination $\left(R^{2}\right)$ of leaf miner in relation to weather parameters at two locations in the Nilgiris

\begin{tabular}{llll}
\hline $\begin{array}{l}\text { Location of Trap } \\
\text { catches of adult leaf } \\
\text { miner }\end{array}$ & Regression equation & $\begin{array}{l}\text { Correlation } \\
\text { Coefficient (R) }\end{array}$ & $\begin{array}{l}\text { Coefficient of } \\
\text { determination } \\
\left.\mathbf{( R}^{2}\right)\end{array}$ \\
\hline Ooty & $\mathrm{Y}_{1}=5.901+2.015(\mathrm{~T} \cdot \mathrm{max})-0.564(\mathrm{GDD})+3.145$ & 0.679 & 0.461 \\
Kotagiri & $\begin{array}{l}\mathrm{Y}_{2}=-30.880-163.415(\mathrm{~T} \cdot \mathrm{max})-80.500(\mathrm{DV})+ \\
1680224(\mathrm{GDD})+4.666\end{array}$ & 0.809 & 0.655 \\
\hline
\end{tabular}


inferred that management should begin in the early stages of the crops to prevent pest buildup in the later stages.

\section{Conflict of interest}

The authors declare that they have no conflict of interest.

\section{REFERENCES}

1. Chavez, G. L. \& Raman, K. V. (1987). Evaluation of trapping and trap types to reduce damage to potatoes by the leaf miner, Liriomyza huidobrensis (Diptera, Agromyzidae). International Journal of Tropical Insect Science, 8 (3), 369-372. https://doi.org/10.1017/S17427584000054 03.

2. Colting, L. M., Mangili, T. K., Ligat, B. S., Olo-an, R. \& Pagadan, C. S. (2003). Yellow sticky trap as tool in managing potato leafminer, Liriomyza huidobrensis (Blanchard). Philippine Journal of Crop Science (Philippines), 28, 65.

3. Durairaj, C., Shobanadevi, R., Suresh, S. \& Natrajan, S. (2006). A non-chemical method for the management of leaf miner Liriomyza trifolii and whitefly Bemisia tabaci in brinjal. In I International Conference on Indigenous Vegetables and Legumes. Prospectus for Fighting Poverty, Hunger and Malnutrition,752,527-530. https://doi.org/10.1 7660/ActaHortic.2007.752.98.

4. Galande, S. M., Mote, U. N. \& Ghorpade, S. A. (2004). New host plants of serpentine leaf miner, Liriomyza trifolii in western Maharashtra. Annals of Plant Protection Sciences, 12(2), 438-439.

5. Ganapathy, N., Durairaj, C. \& Karuppuchamy, K. (2010). Bio-ecology and management of serpentine leaf miner, Liriomyza trifolii (Burgess) in cowpea. Karnataka Journal of Agricultural Sciences, 23(1), 159-160.

6. Kroschel, J., Mujica, N., Alcazar, J., Canedo V. \& Zegarra, O. (2012). Developing Integrated Pest Management for Potato: Experiences and Lessons from Two Distinct Potato Production Systems of Peru. In: He Z., Larkin R., Honeycutt W. (eds) Sustainable Potato Production: Global Case Studies. Springer, Dordrecht, 419-450. https:// doi.org/10.1007/978-94-007-4104-1_25.

7. Mazumdar, S. \& Bhuiya, B. A. (2015). Correlation be- tween climatic factors and leafminer (Insecta: Agromyzidae) infestation on three vegetable crops in Chittagong, Bangladesh. Journal of the Asiatic Society of Bangladesh, Science, 41(1), 1-5.

8. Neupane, F. P. (2000). Integrated pest management of vegetable insects (In Nepali). Centre for Environmental and Agricultural Policy Research, Extension and Development (CEAPRED), Bakhundol, Lalitpur, Nepal, 165-172.

9. Reddy, N. A. \& Kumar, C. T. (2005). Influence of weather factors on abundance and management of serpentine leaf minor, Liriomyza trifolii (Burgess) on tomato. Annals of Plant Protection Sciences, 13(2), 315-318.

10. Reader, J. (2008). Propitious esculent: The potato in world history. Random House.

11. Rose, M., Barekye, A., Joseph, E., Gerald, K., Innocent, U. \& Sarah, K. (2019). Management of potato leaf miner in Uganda. African Journal of Agricultural Research, 14(19), 813-818.

12. Shepard, B. M. \& Braun, S. A. R. (1998). Seasonal incidence of Liriomyza huidobrensis (Diptera: Agromyzidae) and its parasitoids on vegetables in Indonesia. International Journal of Pest Management, 44(1), 4347.

13. Soltani, A., Abda, M. B., Amri, M., Carapelli, A. \& Jemâa, J. M. B. (2020). Seasonal incidence of the leaf miner Liriomyza cicerina Rond (Diptera: Agromyzidae) in chickpea fields and effects of climatic parameters, chickpea variety, and planting date on the leaf miner infestation rate. EuroMediterranean Journal for Environmental Integration, 5(3), 1-10.

14. Unmole, L., Abeeluck, D. \& Seetohul, R. (2001). Yellow sticky traps as a monitoring tool for effective control of leaf miners in onion. Food and Agricultural Research Council, 93.

15. Weintraub, P. G. (2001). Changes in the dynamics of the leaf miner, Liriomyza huidobrensis, in Israeli potato fields. International Journal of Pest Management, 47(2), 95-102. https://doi.org/10.1080/09670870151130516.

16. Yabas, C., Ulubilir, A. \& Yigit, A. (2000). Effect of mass trapping by yellow sticky traps in controlling of leafminer, Liriomyza spp. (Diptera: Agromyzidae) injurious on vegetables in greenhouses in Icel. Effect of mass trapping by yellow sticky traps in controlling of leafminer, Liriomyza spp. (Diptera: Agromyzidae) injurious on vegetables in greenhouses in Icel., 23(1), 145-149. 